\title{
LINGKUNGAN PENDIDIKAN ISLAMI DAN HUBUNGANNYA DENGAN MINAT BELAJAR PAI SISWA SMA NEGERI 10 BOGOR
}

\author{
M. Dahlan R, Lela Qodriah \\ Dosen tetap Fakultas Agama Islam UIKA Bogor \\ Mahasiswa FAI UIKA Bogor \\ dahlan@uika-Bogor.ac.id
}

Received: 24-07-2018, Accepted: 13-08-2018, Publish: 03-09-2018

\begin{abstract}
The environment of Islamic education and its relationship with the learning interest of PAI students of the 10th State High School in Bogor. The research aims to find out the environment of Islamic education and its relationship with the interest in learning PAI students in 10 senior high schools in Bogor. The population amounted to 295 students from the whole class 10, and the samples were 45 students. The method used is quantitative and questionnaire as an instrument, the research hypothesis testing is done using correlation and regression analysis, data analysis using Pearson Correlation statistical analysis. The results of this study indicate that a positive relationship between Islamic education environment variables and PAI learning interest variables are calculated by Pearson Correlation, the value of the correlation coefficient obtained between these variables is 0.770 . The coefficient of determination in this analysis obtained a value of 0.541 , which means that $59.3 \%$ of PAI learning interest variables can be explained from the environment variables of Islamic education. Based on the results of the study it can be said that the environment of Islamic education (X1) has a relationship with the interest in learning Islamic Education (Y) students of SMA Negeri 10 Bogor.
\end{abstract}

Keywords: environment, Islamic education, interest in learning, PAI

\begin{abstract}
Abstrak
Lingkungan pendidikan islami dan hubungannya dengan minat belajar PAI siswa Sekolah Menengah Atas Negeri 10 Bogor. Penelitian bertujuan untuk mengetahui Lingkungan pendidikan islami dan hubungannya dengan minat belajar PAI siswa di Sekolah Menengah Atas Negeri 10 bogor. Populasi berjumlah 295 siswa dari keseluruhan kelas 10, dan yang dijadikan sampel berjumlah 45 siswa. Metode yang digunakan adalah kuantitatif dan kuesioner sebagai instrumen, pengujian hipotesis penelitian dilakukan dengan menggunakan analisis korelasi dan regresi, Analisis data menggunakan analisis statistik Pearson Correlation. Hasil penelitian ini menunjukkan bahwa hubungan positif antara variabel lingkungan pendidikan islami dan variabel minat belajar PAI dihitung dengan Pearson Correlation, nilai koefisien korelasi yang diperoleh antara variabel tersebut sebesar 0.770 . Nilai koefisien determinasi dalam analisis ini diperoleh nilai 0,541 yang berarti 59,3\% variabel minat belajar PAI bisa dijelaskan dari variabel lingkungan pendidikan islami. Berdasarkan hasil penelitian dapat dikatakan bahwa lingkungan pendidikan islami (X1) memiliki hubungan dengan minat belajar Pendidikan Agama Islam (Y) siswa SMA Negeri 10 Bogor.
\end{abstract}

Keywords: lingkungan, pendidikan islami, minat belajar, PAI 


\section{PENDAHULUAN}

Lingkungan merupakan bagian dari penentu keberhasilan sebuah pembelajaran, yang menjadi faktor pendorong munculnya minat dalam belajar lingkungan belajar pada hakikatnya adalah suatu interaksi antar individu dengan lingkungan. Interaksi lingkungan yang dilakukan individu merupakan respon terhadap lingkungan yang memberikan rangsangan. Dalam proses interaksi itu dapat terjadi perubahan pada diri individu berupa perubahan tingkah laku baik bersifat positif maupun bersifat negatif ${ }^{1}$. Lingkungan merupakan sumber belajar yang banyak berpengaruh dalam proses belajar maupun perkembangan anak ${ }^{2}$. Lingkungan yang baik akan memberikan kenyamana kepada siswa mengikuti proses belajar mengajar, kenyamanan dalam belajar sudah barangtentu akan mendorong siswa mengikuti belajar dengan giat dan sungguhsunguh.

Sedangkan minat belajar PAI adalah merasa suka sehingga menimbulkan keterikatan pada pelajaran PAI tanpa paksaan. Minat belajar yang ada pada diri siswa akan mendorong belajar lebih giat

1 Muhammad Anwar. (2016). Lingkungan Pendidikan Dalam Al-Qur'an, Istiqra; Jurnal Penelitian Ilmiah, LP2M IAIN Palu. 4 (02), hlm. 222.

2 Muhammad Muhlis. (2016). Pengaruh Lingkungan Keluarga Dan Lingkungan Sekolah Terhadap Prestasi Belajar Siswa Kelas 6 Sdn Limbangan, Syntax Literate; Jurnal Ilmiah Indonesia. 1 (04), hlm. 1. untuk memahami sehingga dengan sendirinya ia akan lebih menguasai pelajaran dibandingkan dengan siswa lain. PAI merupakan pelajaran yang ada di Sekolah Menengah Atas, pelajaran yang membahas mengenai seluk beluk ajaran Islam dengan tujuan merubah cara berpikir siswa normatif dan tekstual kepada cara berpikir empiris dan mampu memberikan tafsiran makna dalam memahami dan menjelaskan ajaran dan nilai-nilai Islam serta mau mengamalkannya di tengahtengah kehidupan.

Sebagai sebuah mata pelajaran, PAI tentu membutuhkan dorongan untuk dipelajarai secara mendalam agar dapat dipraktekkan sehari-hari, satu diantara dorongan itu adalah adanya lingkungan islami. Dari sekian banyak sekolah yang membiasakan adanya praktek ajaran Islam adalah Sekolah Menengah Atas 10 Bogor.

Berangkat dari pemaparan tersebut maka permasalahan yang ingin dikaji adalah: "Apakah terdapat hubungan antara lingkungan pendidikan islami dan dengan minat belajar PAI siswa Sekolah Menengah Atas Negeri 10 Bogor".

\section{TINJAUAN PUSTAKA}

\section{Lingkungan Pendidikan Islami}

Lingkungan meliputi semua bentuk keadaan yang dapat mempengaruhi tingkah 
laku, pertumbuhan dan perkembangan seseorang di dunia ini. Menurut Mohammad Surya, lingkungan adalah segala hal yang merangsang individu, sehingga individu turut terlibat dan mempengaruhi perkembangannya ${ }^{3}$. Menurut Zakiah Daradjat, dalam arti yang luas lingkungan mencakup iklim dan geografis, tempat tinggal, adat istiadat, pengetahuan, pendidikan dan alam ${ }^{4}$.

Menurut definisi luas ini, ternyata di dalam lingkungan seseorang atau di sekitarnya tidak hanya terdapat sejumlah faktor-faktor yang secara potensial sanggup atau dapat mempengaruhi perkembangan dan tingkah lakunya. Akan tetapi, lingkungan yang aktual hanyalah faktor-faktor dalam dunia sekelilingnya, yang benar-benar secara langsung mempengaruhi pertumbuhan dan tingkah laku, lingkungan itu menjadi tiga bagian sebagai berikut yaitu: lingkungan alam atau luar, lingkungan dalam dan lingkungan sosial ${ }^{5}$.

Respon terhadap lingkungan itu sendiri berbeda-beda, dalam pandangan Syaodih memahami lingkungan secara

${ }^{3}$ Mohamad Surya. (2014). Psikologi Guru: Konsep Dan Aplikasinya. Bandung: Alfabeta, hlm. 34.

${ }^{4}$ Zakiyah Darazjat, Zakiah Drajat. (2012). Ilmu Pendidikan Islam. Jakarta: Bumi Aksara, hlm. 86.

${ }^{5}$ Ngalim Purwanto. (2007). Ilmu Pendidikan Teori dan Praktis. Bandung: PT Remaja Rosdakarya, hlm. 72. garis besar ada dua kecenderungan interaksi individu dengan lingkungan, yaitu: (a) individu menerima lingkungan, dan (b) individu menolak lingkungan ${ }^{6}$. Sesuatu yang datang dari lingkungan mungkin diterima oleh individu sebagai sesuatu yang menyenangkan atau tidak menyenangkan, menguntungkan atau merugikan. Sesuatu yang menyenangkan atau menguntungkan akan diterima oleh individu, tetapi yang tidak menyenangkan atau merugikan akan ditolak atau dihindari ${ }^{7}$. Hal ini tidak terbatas pada lingkungan tempat berlangsungnya aktifitas kehidupan, namun juga dalam proses pendidikan.

Sedangkan Pendidikan secara etimologi memiliki tiga makna yaitu; Pertama. Rabaa yarbuu memiliki arti bertambah dan bertumbuh. Kedua. Rabiya yarba artinya menjadi besar. Ketiga. Rabba yarubbu yang bermakna memperbaki, memelihara, membentuk dan mendidik $^{8}$. Dalam terminologi, Ahmad Tafsir memaknai pendidikan sebagai usaha yang dilakukan oleh seseorang (pendidik) terhadap seseorang (anak didik) agar

\footnotetext{
${ }^{6}$ Nana Syaodih Sukmadinata. (2011). Landasan Psikologi Proses Pendidikan. Bandung : PT Remaja Rosakarya Offset, hlm. 57.

7 Nana Syaodih Sukmadinata. (2011). hlm. 57.

${ }^{8}$ Louis Ma'luf. (1987). Al Munjid fî allughah wal a'lâm. Beirut: Dar al Masriq, hlm. 234.
} 
tercapai perkembangan maksimal yang positif, usaha itu banyak macamnya, diantaranya dengan cara mengajarnya yaitu mengembangkan pengetahuan dan keterampilannya, memberikan contoh (teladan) agar ditiru, membiasakan, memberikan pujian dan hadiah, dan lainlain ${ }^{9}$.

Jika lingkungan dan pendidikan disatukan menjadi sebuah kalimat maka akan memiliki makna sebagai tempat berlangsungnya pengembangan diri seseorang. Lingkungan dalam proses pendidikan adalah tempat di mana diberlangsungkannya pendidikan, dalam pandangan Syafi'i lingkungan pendidikan adalah suatu institusi atau kelembagaan dimana pendidikan berlangsung, lingkungan itu akan memengaruhi proses pendidikan yang berlangsung ${ }^{10}$, pemaknaan lebih luas disampaikan Soemanto dalam Ramdani lingkungan pendidikan mencakup segala materiil dan stimuli di dalam dan di luar diri individu, baik yang bersifat fisiologis, psikologis, maupun sosio-kulutral ${ }^{11}$.

9 Ahmad Tafsir. (2008). Ilmu Pendidikan dalam Prespektif Islam. Bandung: Remaja Rosda Karya, hlm. 28.

${ }^{10}$ A. Syafi'i AS. (2015). Perubahan

Lingkungan Pendidikan dan cara mengantisipasinya, Dirasat; Jurnal Menejemen dan Pendidikan Islam. 01 (01), hlm. 153.

11 Muhammad Ali Ramdhani. (2014). Lingkungan Pendidikan dalam Implementasi
Dalam proses pendidikan lingkungan berperan sangat penting, perkembangan dan pembentukan perilaku individu dipengaruhi oleh lingkungan baik secara fisik maupun lingkungan sosio-psikologis, termasuk di dalamnya adalah belajar. Terhadap faktor lingkungan ini ada pula yang menyebutnya sebagai empirik yang berarti pengalaman, karena dengan lingkungan itu individu mulai mengalami dan mengecap alam sekitarnya ${ }^{12}$. Kompetensi yang ada dalam diri dapat berkembang dalam lingkungan pendidikan, ia juga sebagai sarana untuk mengembangkan kepekaan sosial. Karena itulah lingkungan pendidikan merupakan berbagai faktor lingkungan yang berpengaruh terhadap praktek pendidikan atau berbagai lingkungan tempat berlangsungnya proses pendidikan, yang merupakan bagian dari lingkungan sosial ${ }^{13}$. Dengan demikian, lingkungan turut menentukan pada berhasil atau tidaknya pendidikan yang dilaksanakan ${ }^{14}$.

Pendidikan Karakter, Jurnal Pendidikan Universitas Garut, 08 (01), hlm. 34.

12 Abdul Latief. (2014). Pengaruh Lingkungan Sekolah Terhadap Hasil Belajar Pendidikan Kewarganegaraan Pada Peserta Didik Di Smk Negeri Paku Kecamatan Binuang Kabupaten Polewali Mandar, Jurnal Pepatuzdu, 7 (1), hlm. 6.

${ }^{13}$ Hadi Kunaryo. (1999). Pengantar

Pendidikan. Semarang: IKIP Semarang Press. hlm. 62.

${ }^{14}$ Moh. Miftahul Choiri. (2017). Upaya Pemanfaatan Lingkungan Sekitar Sebagai Sumber Belajar Anak, Jurnal Refleksi Edukatika 8 (1). 
Betapa pentingnya lingkungan dalam sebuah proses pendidikan sehingga tidak ada satupun lingkungan yang tidak berperan dalam kesuksesan dan keberhasilan sebuah pendidikan. Pada proses pendidikan perlu perhatian dan usaha yang sungguh-sungguh dalam menciptakan lingkungan pendidikan karena segala sesuatu yang terjadi di lingkungan pendidikan akan diserap dan dijadikan contok oleh anak didik. Upaya menciptakan lingkungan belajar efektif adalah tuntutan insituti sebagai tanggung jawab guru dan tenaga pendidikan lainnya, Lingkungan efektif itu mencangkup dua hal, keduanya dapat membantu menerapkan prinsip-prinsip belajar di atas, yaitu lingkungan fisik dan non- fisik yang mencangkup lingkungan belajar non-fisik adalah suasana emosional diri siswa itu sendiri, keadaan sosial ekonominya, kesemangatan dan perkembangan intelektualnya $^{15}$.

Lingkungan islami adalah lingkungan yang memiliki kedamian di dalamnya, dan berlangsung kegiatan atau aktifitas-aktifas yang mencerminkan kepatuhan dan penyerhaan diri kepada Allah SWT. Menurut Abuddin Nata lingkungan Islami adalah lingkungan atau

15 Cece Wijaya. (2010). Pendidikan Remedial. Bandung: Ramaja Rosdakarya, hlm. 153 . tempat sangat berguna untuk menunjang suatu kegitan, termasuk kegiatan pendidikan, karena tidak ada satu pun kegiatan yang tidak memerlukan tempat dimana kegiatan itu diadakan. Sebagai lingkungan tarbiyah islamiyah, ia mempunyai fungsi antara lain menunjang terjadinya kegiatan proses belajar mengajar secara aman, tertib, dan berkelanjutan ${ }^{16}$.

Lingkungan pendidikan Islam secara umum adalah upaya menjadikan manusia mampu untuk mewujudkan tujuan penciptaannya. Manusia diciptakan agar mereka mengetahui hakikat Tuhannya, mengesakan Memurnikan ibadah kepada Tuhannya, dan mau menghambakan diri dengan menjalankan seluruh perintahnya dan menjauhi semua larangannya.

Lingkungan pendidikan Islam diarahkan untuk megingatkan keyakinan, pemahman, penghayatan dan pengalaman ajaran agama Islam dari peserta didik, yang disamping untuk membentuk kesalehan sosial. Dalam arti kualitas atau kesalehan pribadi itu diharapkan mampu memancarkan luar dalam hubungan keseharian dengan manusia lainnya (bermasyarakat), baik yang seagama

16 Abuddin Nata. (2013). Filsafat Pendidikan Islam. Jakarta: Gaya Media Pratama, hlm. 164. 
(sesama muslim) ataupun yang berbangsa dan bernegara ${ }^{17}$.

Lingkungan pendidikan Islami harus melakukan berbagi pendekatan pembiasaan hal ini diungkapkan oleh Syaiful Bahri Djamarah bahwa pembiasaan adalah alat pendidikan. Bagi anak pembiasaan ini sangat penting, karena aktivitas akan dimilki anak jika itu dibiasakan,pembiasaan yang dilakukan akan membentuk sebuah pribadi di kemudian hari.pribadi yang baik karena pembiasaannya yang baik. Sebaliknya, pembiasaan yang buruk akan membentuk sosok manusia yang berkepribadian yang buruk pula. Maka alangkah penting, pada awal kehidupan anak,pembiasaan akan perbuatan yang baik perlu ditanamkan dan hindari pembiasaan yang buruk seperti berdusta, tidak disiplin, suka berkelahi, dan sebagainya.tetapi tanamkanlah kebiasan seperti ikhlas melakukan puasa, gemar melakukan shalat lima waktu, aktif berpartisipasi dalam kegiatan yang baikbaik $^{18}$.

\section{a. Ciri-ciri lingkungan islami}

Tidak semua sekolah sebagai lingkungan belajar menjadi lingkungan islami, keberadaan lingkungan islami

\footnotetext{
${ }^{17}$ Muhaimin, Paradigma Pendidikan Islam, (Bandung: PT Remaja Rosdakarya, 2012), hal.76.

${ }^{18}$ Syaiful Bahri Djamarah, Strategi Belajar Mengajar, ( Jakarta: Rineka Cipta, 2010), hal.6263.
}

memang tida bisa dipisahkan dengan praktek kehidupan Islam, atau lingkungan yang menjadi tempat pelaksanaan ajaran Islam, sehingga dengan demikian lingkungan islami memliki kriteria dan ciri tersendiri. Menurut Muhaimin ciri lingkungan islami yang berada dilingkungan sekolah yaitu:

1. Terampil bergairah beribadah, maupun berzikir, dan berdoa

2. Membaca Al-Qura'an dan menulisnya dengan benar

3. Terbiasa berkepribadian muslim (berakhlak mulia)

4. Terbiasa menerapkan aturanaturan dasar Islam dalam kehidupan sehari-hari ${ }^{19}$.

Syaikh Fuhaim Musthafa menjelaskan lingkungan islami adalah lingkungan di mana anakanak didik selalu:

1. Membiasakan anak-anak senang membaca Al-Qur'an dan mengafalkannya.

2. Menganjurkan anak untuk shalat tepat pada waktunya

3. Melatih anak bersabar dan ridjha terhadap penyakit dan problematika yang menimpanya

4. Mengajari anak agar memahami pentingnya cinta kepada Allah dan Rasullnya, seta mengajarinya sifat-sifat mulia lainnya, seperti bertaubat, bersabar, bersyukur, bertawaka, dan ikhlas

\footnotetext{
${ }^{19}$ Muhaimin. (2012). Paradigma Pendidikan Islam. Bandung: PT Remaja Rosdakarya, hlm. 8081.
} 
5. Memahami anak selalu akan pentingnya menyucikan hati dari penyakit iri, cemburu, dengki, membenci, dan dendam

6. Selalu menyediakan programprogram tayangan yang sesuai kapasitas akal dan umur anak, agar tertanam pada diri mereka nilai-nilai Islami ${ }^{20}$.

Lingkungan islami juga diungkapkan oleh Nasution di dalam lingkungan sekolah guru menanamkan norma-norma yang berlaku bagi golongan menengah misalnya menghargai nilai-nilai seperti kejujuran, kebersihan, kerajinan, rasa tanggung jawab, ketekunan, ketertiban, dan sebagainya. Perbuatan seperti penipuan, kekerasan, pelanggaran seks, pencurian dipandang sebagai tindakan yang melanggar norma yang baik ${ }^{21}$. Ciri lingkungan islami yang berada di lingkungan sekolah yaitu; Pertama. Siswa melaksanakan atau menjalankan kehidupan beribadah dengan benar. Kedua, Siswa mampu membiasakan adab sopan santun

20 Syaikh Fuhaim Musthafa. (2015). Kurikulum Pendidikan Anak Muslim. Surabaya: Pustaka elba, hlm.20-21.

${ }^{21}$ Nasution. (2014). Sosiologi Pendidikan. Jakarta: PT Bumi Aksara, hlm.133. yang baik yang baik sesuai dengan ajaran agama Islam. ${ }^{22}$

\section{b. Peran lingkungan Pendidikan}

\section{Islami}

Dasar perubahan perilaku seseorang adalah pendidikan yang ia terima selama hidupnya, segala sesuatu yang diterima manusia melalui panca indra itu menjadi bagian dari pendidikan, melihat, mendengar, merasa, dan meraba merupakan komponen penting dalam pendidikan, dan itu sangat-sangat mudah ia dapatkan dari lingkungan, baik dari lingkungan pendidikan formal atau nonformal $^{23}$, dan ini sangat berpengaruh terhadap perkembangan potensi anak didik

Mulyasa berpendapat bahwa peran lingkungan dalam membangun sikap dan spritual dan sikap soial dengan lingkungan adalah lingkungan yang aman, nyaman dan tertib merupakan suasana yang membangkitkan gairah dan semangat belajar. Iklim yang demikian akan mendorong terciptanya masyarakat belajar, karena iklim belajar yang kondusif merupakan tulang punggung dan faktor pendorong yang dapat memberikan daya tarik tersendiri bagi proses belajar,

${ }^{22}$ Ahmad Susanto. (2013). Teori Belajar \& Pembelajaran di Sekolah Dasar. Jakarta: Prenadamedia Grup, hlm. 227.

23 Setyo Watieni. (2011). Lingkungan Sekolah dalam pendidikan. (https:// setyowatieni. wordpress.com/2011/06/21/peran -lingkungan sekolah-dalam-pendidikan/\#more-48). 
sebaliknya iklim belajar yang kurang menyenangkan akan menimbulkan kejenuhan dan rasa bosan ${ }^{24}$. Selain itu lingkungan pendidikan Islami akan berperan dalam membina masyarakat suapaya mempunayai aqidah yang mantap serta berakhlakul karimah

\section{Minat Belajar}

\section{a. Pengertian minat belajar}

Minat pada dasarnya adalah penerimaan akan suatu hubungan antara diri sendiri dengan sesuatu di luar diri, semakin kuat atau dekat hubungan tersebut, semakin besar minat ${ }^{25}$. Minat selalu diikuti dengan perasaan senang, dan dari situ diperoleh suatu keputusan ${ }^{26}$.

Minat dapat terlihat dari rasa suka yang lebih dari pada yang lain, bisa juga melalui keikutsertaan dalam sebuah aktifitas, karena kecenderungan seseorang terhadap sesuatu dapat dilihat dalam memberikan perhatian yang lebih besar dibandingkan kepada yang lainnya, hal itu menandakan adanya minat karena itu minat tidak dibawa sejak lahir, akan tetapi muncul setlah adanya kecenderungan.

${ }^{24}$ Mulyasa. (2014). Implementasi Kurikulum 2013. Bandung: PT Remaja Rosdakarya, hlm. 118.

${ }^{25}$ Slameto. (2013). belajar dan faktor-faktor yang mempengaruhi. Jakarta: Rineka Cipta, hlm. 180.

26 Nursyaida. (2014). Faktor-Faktor Yang Mempengaruhi Belajar Peserta Didik. IAIN-Padangsidimpuan; Jurnal Pendidikan Agama Islam. hlm. 74.
Dalam pandangan Muhibbin Syah dalam Slamento minat secara sederhana, minat (interest) berarti kecenderungan yang tinggi atau keinginan yang besar terhadap sesuatu. Minat yang dipahami dan dipakai oleh orang selama ini dapat mempengaruhi kualitas pencapaian hasil belajar siswa dalam bidang-bidang studi tertentu ${ }^{27}$. Nyayu Khodijah berpendapat minat adalah adanya minat terhadap objek yang dipelajari akan mendorong orang untuk mempelajari sesuatu dan mencapai hasil belajar yang maksimal, karena minat merupakan komponen psikis yang berperan mendorong seseorang untuk meraih tujuan yang diinginkan, sehingga ia bersedia melakukan kegiatan berkisar objek yang diminati ${ }^{28}$.

\section{b. Cara Meningkatkan minat}

Minat dapat dibangkitkan dengan menggunakan minat yang telah ada pada diri siswa, misalnya siswa minat pada membaca al-Qur'an, maka sebelum mengajarkannya, dapat diceritakan bagaimana kelebihan orangorang yang senang dan suka membaca Qur'an, kemudian diarahkan materi yang akan diajarkan.

27 Muhibbin Syah. (2014). Psikologi Pendidikan. Bandung: Remaja Rosdakarya, hlm.133-134.

28 Nyayu Khodijah. (2014). Psikologi Pendidikan. Jakarta: Raja Grafindo Persada, hlm.59. 
Untuk membangkitkan minat belajar anak, perlu diberikan pemahaman mengenai :

a. Untuk apa mempelajari materi pelajaran yang hendak dipelajari

b. Apa hubungannya materi pelajaran tersebut dengan kehidupan sehari-hari (penjelasan manfaat mempelajarinya dan apa yang dapat dia lakukan dengan pengetahuan tersebut.)

c. Bagaimana cara mempelajarinya ${ }^{29}$.

Iklim belajar yang menyenangkan, tidak mengancam, memberi semangat dan sikap optimisme bagi siswa dalam belajar, cenderung akan mendorong seseorang untuk tertarik belajar, memiliki toleransi terhadap suasana kompetisi dan tidak khawatir akan kegagalan ${ }^{30}$.

\section{c. Mata Pelajaran Pendidikan}

\section{Agama Islam (PAI)}

Menurut para ahli Pendidikan Islam adalah pendidikan yang berwarna Islam, Pendidikan Islam adalah pendidikan yang didasarkan

29 Sri Utami, Marthinus, dan Marzuki. (2013). Peningkatan Minat Belajar Dengan Menggunakan Metode Inquiry Pada Pembelajaran Ipa Di Kelas V Sekolah Dasar. Untar: Jurnal Pendidikan dan Pembelajaran, 2 (4), hlm.4.

30 Siti Suprihatin. (2015). Upaya Guru Dalam Meningkatkan Motivasi Belajar Siswa, UM Metro Jurnal Pendidikan Ekonomi, 3 (1), hlm, 72.
Islam $^{31}$. Zuahirini Pendidikan Agama

Islam adalah usaha lebih sistematis dan pragmatis dalam membantu anak didik supaya mereka hidup sesuai dengan ajaran Islam $^{32}$. Jadi PAI adalah pendidikan yang mengajarkan seluk beluk ajaranajaran Islam, agar dapat dipahami dan diamalkan sehingga kehidupannya sesuai dengan Islam. Oleh karena itu, ketika PAI disebut, maka akan mencakup dua hal, yaitu:

a) Mendidik peserta didik untuk berperilaku sesuai dengan nilai-nilai atau akhlak Islam b) Mendidik peserta didik untuk mempelajari materi ajaran agama Islam $^{33}$.

Secara umum Pendidikan Agama Islam merupakan mata pelajaran yang dikembangkan dari ajaran-ajaran Agama Islam yang termaktub dalam al-Qur'an dan al Sunnah yang dikembangkan oleh para ulama melalui ijtihad, dikembangkan pada tataran yang

\footnotetext{
31 Ismail SM. (2009). Strategi Pembelajaran PAIKEM. Semarang: Rasail Media Graup, hlm. 34.

32 Zuhairini. (1983). Metode Khusus Pendidikan Islam. Surabaya: Usaha Nasional, hlm. 27.

${ }^{33}$ Muhaimin, dkk. (2001). Paradigma

Pendidikan Islam, Upaya Mengefektifkan

Pendidikan Agama Islam di Sekolah. Bandung: PT. Remaja Rosdakarya, hlm.75-76.
} 
lebih rinci agar mudah difahami oleh anak didik.

1. Tujuan pembelajaran PAI

Secara umum proses pendidkan harus selalu diarahkan pada usaha pengembangan potensi individu, sehingga manusia tersebut sampai dapat memahami dan mengetahui jati diri dan tanggungjawabnya sebagai mahluk hidup ${ }^{34}$, karena itu yang menjadi tujuan PAI adalah menjadikan manusia sebagai insan pengabdi kepada khaliqnya dan mengelola alam semesta sesuai yang telah ditetapkan oleh Allah $^{35}$.

Adapun tujuan PAI di SMA adalah sebagai berikut:

a. Siswa diharapkan mampu membaca al-Qur'an, menulis dan memahami ayat al-Qur'an serta mampu

mengimplementasikannya didalam kehidupan sehari-hari

b. Beriman kepada Allah SWT, malaikat-malaikat-Nya, kitabkitab-Nya, rasul-rasul-Nya, kepada hari kiamat dan qadha dan qadar-Nya. Dengan mengetahui fungsi dan hikmahnya serta terefleksi dalam sikap, prilaku dan

${ }^{34}$ Su'dadah. (2014). Kedudukan Dan Tujuan Pendidikan Agama Islam Di Sekolah. Jurnal Kependidikan, II (2) hlm. 151.

35 Samsul Nizar. (2000). Dasar-Dasar Pemikiran Pendidikan Islam. Padang: IAIN IB Press, hlm. 92-93. akhlak peserta didik pada dimensi kehidupan sehari-hari

c. Siswa diharapkan terbiasa berperilaku dengan sifat terpuji dan menghindari sifat-sifat tercela, dan bertata kerama dalam kehidupan sehari-hari

d. Siswa diharapkan mampu memahami sumber hukum dan ketentuan hukum Islam tentang ibadah, muamalah, mawaris, munakahat, jenazah dan mampu mengamalkannya dalam kehidupan sehari-hari

e. Siswa diharapkan mampu memahami, mengambil manfaat dan hikmah perkembangan Islam di Indonesia dan dunia serta mampu menerapkannya dalam kehidupan sehari-hari ${ }^{36}$.

2. Ruang Lingkup Pembelajaran PAI Ruang lingkup PAI keserasian, kelarasan dan keseimbangan antara lingkungan manusia dengan Allah S.W.T., hubungan manusia dengan manusia dan hubungan manusia dengan dirinya sendiri serta hubungan manusia dengan lingkungan dan makhluk lainnya ${ }^{37}$. Dalam pendidikan agama Islam terdapat tiga materi pokok yaitu akidah, ibadah dan

${ }^{36}$ Abdul Majid. (2005). Pendidikan Agama Islam Berbasis Kompetensi. Bandung: Remaja Rosda Karya, hlm. 42.

37 Ramayulis. (2010). Metodologi Pendidikan Agama Islam. Jakarta: Kalam Mulia, hlm. 22 . 
$\operatorname{akhlak}^{38}$. Ruang lingkup ini kemudian dituangkan dalam lima tema besar yaitu; Al-Qur'an, Keimanan, Akhlak, Fikih/ibadah dan Tarikh.

Dari uraian tersebut dapatlah dijadikan dasar dalam pengambilan hipotesis yaitu;

$\mathrm{H}_{1}$ : Terdapat hubungan antara lingkungan pendidikan islami dengan minat belajar PAI siswa Sekolah Menengah Atas Negeri 10 Bogor.

\section{METODE PENELITIAN}

Penelitian dilaksanakan di SMA Negeri 10 Bogor. Waktu pelaksanakan selama 6 (enam) bulan, mulai dari bulan maret sampai dengan bulan Juli 2016.

Populasi targetnya siswa di kelas X SMAN 10 Bogor yang berjumlah 295 orang siswa. Sampel Penelitian adalah 45 orang.

Instrumen yang digunakan sebagai pengumpul data penelitian adalah kuesioner berjumlah 15 butir pernyataan untuk masing-masing variabel lingkungan pendidikan islami dan minat belajar PAI . Dari kuesioner tersebut memiliki

${ }^{38}$ Abdul Rahman. (2012). Pendidikan Agama Islam Dan Pendidikan Islam - Tinjauan Epistemologi Dan Isi, JURNAL EKSIS Polnes, 8 (1), hlm. 20157. reliabilitas (menggunakan Alpha Croanbach) 0,712 untuk variabel lingkungan pendidikan islami dan 0,696 untuk minat belajar Pendidikan Agama Islam.

Data hasil penelitian dianalisis menggunakan uji analisis anava satu jalan dengan menggunakan bantuan program SPSS-PC 20.0 for windows. Pengujian hipotesis dilakukan pada taraf signifikansi 0.05 .

\section{HASIL PENELITIAN DAN}

\section{PEMBAHASAN}

\section{Hasil Penelitian}

Dalam pengujian data digunakan analisis statistik yang menyatakan ada hubungan lingkungan pendidikan islami dengan minat belajar PAI di Sekolah Menengah Atas Negeri 10 Bogor.

Untuk itu digunakan analisi regersi dan korelasi dalam mencari kekuatan hubungan antar variabel bebas dan variabel terikat.

Berdasar hasil perhitungan analisis regresi diperoleh nilai kosntanta $a=28,854$ dan koefisien $\mathrm{b}=0,452$, dan dapat dirumuskan persamaan regresi linier sederhana dengan persamaan $\hat{Y}=28,854 \quad \mathrm{x}$ 0,452 . 
Coefficients $^{a}$

\begin{tabular}{|c|c|c|c|c|c|c|}
\hline \multirow{2}{*}{\multicolumn{2}{|c|}{ Model }} & \multicolumn{2}{|c|}{$\begin{array}{c}\text { Unstandardized } \\
\text { Coefficients }\end{array}$} & $\begin{array}{l}\text { Standardized } \\
\text { Coefficients }\end{array}$ & \multirow[t]{2}{*}{$t$} & \multirow[t]{2}{*}{ Sig. } \\
\hline & & $B$ & Std. Error & Beta & & \\
\hline \multirow{2}{*}{1} & (Constant) & 28,854 & 2,947 & & 9,790 & ,000 \\
\hline & LPI & ,452 & ,057 & ,770 & 7,916 &, 000 \\
\hline
\end{tabular}

a. Dependent Variable: MBPAI

ANOVA $^{\mathrm{a}}$

\begin{tabular}{|c|c|c|c|c|c|c|}
\hline \multicolumn{2}{|c|}{ Model } & Sum of Squares & $\mathrm{df}$ & Mean Square & $\mathrm{F}$ & Sig. \\
\hline \multirow{3}{*}{1} & Regression & 294,096 & 1 & 294,096 & 62,662 &, $000^{b}$ \\
\hline & Residual & 201,816 & 43 & 4,693 & & \\
\hline & Total & 495,911 & 44 & & & \\
\hline
\end{tabular}

a. Dependent Variable: MBPAI

b. Predictors: (Constant), LPI

Berdasarkan hasil analisis di atas, uji signifikansi model regresi berdasarkan uji linearitas persamaan garis regresi diperoleh $\mathrm{F}_{\text {hitung }}(\mathrm{b} / \mathrm{a})$ sebesar 62,662 dan p-value $=0.000$ $<0.05$, kesimpulan yang dapat diambil adalah $\mathrm{H}_{0}$ ditolak, sehingga dapat dinyatakan bahwa model persamaan regresi $\mathrm{Y}$ atas $\mathrm{X}$ adalah sangat signifikan.

Hasil pengujian tersebut menjadikan persamaan regresi yang dinyatakan dengan $\hat{Y}=28,854 \mathrm{x}$ 0,452 dapat digunakan untuk menyimpulkan terdapat hubungan antara lingkungan pendidikan islami dengan minat belajar PAI.

Model Summary

\begin{tabular}{|c|c|c|c|c|c|c|c|c|c|}
\hline \multirow{2}{*}{$\begin{array}{l}\text { Mod } \\
\text { el }\end{array}$} & \multirow[t]{2}{*}{$\mathrm{R}$} & \multirow{2}{*}{$\begin{array}{c}\mathrm{R} \\
\text { Square }\end{array}$} & \multirow{2}{*}{$\begin{array}{c}\text { Adjusted } \\
\mathrm{R} \\
\text { Square }\end{array}$} & \multirow{2}{*}{$\begin{array}{c}\text { Std. Error } \\
\text { of the } \\
\text { Estimate }\end{array}$} & \multicolumn{5}{|c|}{ Change Statistics } \\
\hline & & & & & $\begin{array}{c}\text { R Square } \\
\text { Change }\end{array}$ & $\begin{array}{c}\mathrm{F} \\
\text { Change }\end{array}$ & $\mathrm{df1}$ & $\mathrm{df} 2$ & $\begin{array}{c}\text { Sig. F } \\
\text { Change }\end{array}$ \\
\hline 1 &, $770^{\mathrm{a}}$ & ,593 &, 584 & 2,166 & ,593 & 62,662 & 1 & 43 & ,000 \\
\hline
\end{tabular}
a. Predictors: (Constant), LPI
b. Dependent Variable: MBPAI 
Hipotesis yang menyatakan "terdapat hubungan lingkungan pendidikan islami dengan minat belajar PAI", besarnya hubungan ini dihitung dengan menggunakan SPSS. Dari hasil perhitungan diperoleh koefisien korelasi antara $\mathrm{X}$ dengan $\mathrm{Y}$ $\left(\mathrm{r}_{\mathrm{xy}}\right)$ sebesar 0.770 dan $\mathrm{F}_{\text {hitung }}=$ 62,662, sehingga besar koefisien determinasinya $\left(\mathrm{R}^{2}\right)$ sebesar 0.593 Karena $\mathrm{rx}_{\mathrm{y}}$ dikonsultasikan dengan tabel interprestasi nilai didapat bahwa tingkat hubungan kedua variabel adalah kuat atau tinggi. Sehingga dapat disimpulkan bahwa terdapat hubungan positif yang tinggi antara lingkungan pendidikan islami dengan minat belajar PAI.

Hasil pengujian di atas menunjukan adanya hubungan yang berbanding lurus antara kedua variabel, artinya makin baik lingkungan pendidikan islami maka semakin baik minat belajar PAI. Dari koefisien determinasi $\left(\mathrm{R}^{2}\right) 0.593$ atau $59,3 \%$ variansi yang terjadi dalam kecendrungan meningkatnya atau menurunnya minat belajar PAI dapat disebabkan karena lingkungan pendidikan islami.

2. Pembahasan
Hasil analisis data untuk uji hipotesis terdapat hubungan positif lingkungan pendidikan islami dengan minat belajar PAI siswa MAN 10 Bogor. Analisis dilakukan untuk mengetahui arah hubungan variabel lingkungan pendidikan islami (X) dengan variabel minat belajar PAI (Y). Dari hasil analisis korelasi antara kedua variabel penelitian diperoleh bahwa besarnya hubungan antara variabel lingkungan pendidikan islami dan variabel minat belajar PAI dihitung dengan Pearson Correlation, dan diperoleh nilai koefisien korelasi antara variabel tersebut sebesar 0.770. Nilai koefisien determinasi dalam analisis ini diperoleh nilai 0,593 yang berarti $59,3 \%$ variabel minat belajar PAI bisa dijelaskan dari variabel lingkungan pendidikan islami. Hal ini menunjukkan bahwa hubungan antara kedua variabel kuat/tinggi. Dari hasil perhitungan ANOVA dan regresi linear diperoleh bahwa regresi lingkungan pendidikan islami sebesar 0.770 menunjukkan bahwa setiap penambahan nilai lingkungan pendidikan islami sebesar 1 unit akan meningkatkan nilai minat belajar PAI sebesar 28,854. Sedangkan 
standardized coeficients sebesar 0.593 menunjukkan angka korelasi, yang berarti hubungan antara variabel lingkungan pendidikan islami dan variabel minat belajar PAI tinggi atau kuat.

\section{KESIMPULAN}

Hasil hipotesis seperti telah dikemukakan di atas dapat ditarik kesimpulan dari hasil penelitian di MAN 10 Bogor. Terdapat hubungan yang kuat antara variabel lingkungan pendidikan islami dan variabel minat belajar PAI. Artinya semakin baik lingkungan pendidikan islam, akan membuat minat belajar PAI semakin meningkat.

\section{DAFTAR PUSTAKA}

Anwar, M. (2016). Lingkungan Pendidikan Dalam Alqur'an. Istiqra; Jurnal Penelitian Ilmiah, LP2M IAIN Palu. 4 (02).

Arifin, M. (1994). Filsafat Pendidikan Islam. Jakarta:Bumi Aksara.

AS, A. S. (2015). Perubahan Lingkungan Pendidikan dan cara mengantisipasinya. Jurnal Menejemen dan Pendidikan Islam. $01(01)$.

Choiri, M. M. (2017). Upaya Pemanfaatan Lingkungan Sekitar Sebagai
Sumber Belajar Anak. Jurnal Refleksi Edukatika. 8 (01).

Dimyati. (2013). Belajar Dan Pembelajaran. Jakarta: PT Asdi Mahasaty.

Djamarah, S. B. (2010). Strategi Belajar Mengajar. Jakarta: Rineka Cipta.

Khodijah, N. (2014). Psikologi Pendidikan. Jakarta: Raja Grafindo Persada.

Kunaryo, H. (1999). Pengantar Pendidikan. Semarang: IKIP Semarang Press.

Latief, A. (2014). Pengaruh Lingkungan Sekolah Terhadap Hasil Belajar Pendidikan Kewarganegaraan Pada Peserta Didik Di Smk Negeri Paku Kecamatan Binuang Kabupaten Polewali Mandar. Jurnal Pepatuzdu. 7 (01).

Ma'luf, L. ( 1987). Al Munjid fì allughah wal a 'lâm. Beirut: Dar al Masriq.

Majid, A. (2005). Pendidikan Agama Islam Berbasis Kompetensi. Bandung: Remaja RosdaKarya.

Muhaimin. (2012). Paradigma Pendidikan Islam. Bandung: PT Remaja Rosdakarya.

Muhaimin, dkk. (2001). Paradigma Pendidikan Islam, Upaya Mengefektifkan Pendidikan Agama Islam di Sekolah. Bandung: PT. Remaja Rosdakarya.

Muhlis, M. (2016). Pengaruh Lingkungan Keluarga Dan Lingkungan Sekolah Terhadap Prestasi Belajar Siswa 
Kelas 6 SDN Limbangan, Syntax Literate. Jurnal Ilmiah Indonesia. 1 (04).

Mulyasa. (2014). Implementasi Kurikulum 2013. Bandung: PT Remaja Rosdakarya.

Musthafa, S. F. (2015). Kurikulum Pendidikan Anak Muslim. Surabaya: Pustaka elba.

Nana Syaodih, S. (2011). Landasan Psikologi Proses Pendidikan. Bandung : PT Remaja Rosakarya Offset.

Nasution. (2014). Sosiologi Pendidikan. Jakarta: PT Bumi Aksara.

Nata, A. (2013). Filsafat Pendidikan Islam. Jakarta: Gaya Media Pratama.

Nizar, S. (2000). Dasar-Dasar Pemikiran Pendidikan Islam. Padang : IAIN IB Press.

Nursyaida. (2014). Faktor-Faktor Yang Mempengaruhi Belajar Peserta Didik. Jurnal Pendidikan Agama Islam IAIN-Padang.

Purwanto, N. (2007). Ilmu Pendidikan Teori dan Praktis. Bandung: PT Remaja Rosdakarya.

Rahman, A. (2012). Pendidikan Agama Islam Dan Pendidikan Islam Tinjauan Epistemologi Dan Is. JURNAL EKSIS Polnes. 8 (01).

Ramayulis. (2010). Metodologi Pendidikan Agama Islam. Jakarta: Kalam Mulia.
Ramdhani, M. A. (2014). Lingkungan Pendidikan dalam Implementasi Pendidikan Karakter. Jurnal Pendidikan Universitas Garut. 8 (01).

Slameto. (2013). belajar dan faktor-faktor yang mempengaruhi. Jakarta: Rineka Cipta.

SM, I. (2009). Strategi Pembelajaran PAIKEM. Semarang: Rasail Media Graup.

Su'dadah. (2014). Kedudukan Dan Tujuan Pendidikan Agama Islam Di Sekolah. Jurnal Kependidikan. II (02).

Suprihatin, S. (2015). Upaya Guru Dalam Meningkatkan Motivasi Belajar Siswa. Jurnal Pendidikan Ekonomi UM Metro. 3 (01).

Surya, M. (2014). Psikologi Guru: Konsep Dan Aplikasinya. Bandung: Alfabeta.

Susanto, A. (2013). Teori Belajar \& Pembelajaran di Sekolah Dasar. Jakarta: Prenada media Grup.

Syah, M. (2014). Psikologi Pendidikan. Bandung: Remaja Rosdakarya.

Tafsir, A. (2008). Ilmu Pendidikan dalam Prespektif Islam. Bandung: Remaja Rosdakarya.

Utami, S., Martinus, Marzuki. (2013). Peningkatan Minat Belajar Dengan Menggunakan Metode Inquiry Pada Pembelajaran Ipa Di Kelas V Sekolah Dasar. Jurnal Pendidikan dan Pembelajaran Untar. 2 (04). 
Wijaya, C. (2010). Pendidikan Remedial. Bandung: Ramaja Rosdakarya.

Zuhairini. (1983). Metode Khusus Pendidikan Islam. Surabaya: Usaha Nasional.
Watieni, S. (2011). Lingkungan Sekolah dalam pendidikan, https:// setyowatieni. wordpress.com/ 2011/06/21/peran -lingkungan sekolah-dalam-pendidikan/\#more48. 